\title{
EFFECT OF HUMIC ACID, PLANT GROWTH PROMOTING AND METHODS OF APPLICATION ON TWO POTATOES (Solanum tuberosum L.) CULTIVAR GROWN UNDER SANDY SOIL CONDITION
}

\author{
M.M. Arafa ${ }^{(1)}$ and M.A. El-Howeity ${ }^{(2)}$ \\ (1) Department of Sustainable Development of Environment and Management of its Projects \\ (2) Department of Evaluation of Natural Resources and Planning for their Development \\ Environmental Studies and Research Institute, Univ. of Sadat City, Egypt.
}

Received: Jan. 5, 2017

Accepted: Feb. 19, 2017

\begin{abstract}
Two field experiments were carried out during two successive seasons of 2014 and 2015, to study the effect of different seven treatments of bio and organic fertilizers (control, Tricoderma, PGPR, Humic acid, Tri. + PGPR, Tri. + Humic acid and Tri. + PGPR + Humic acid) adding as two types of application as coating and foliar application on vegetative growth characteristics, yield and its components as well as chemical composition ( $N, P, K, F e, M n$ and $\mathrm{Zn)}$ for two cvs. of potato.

Results showed that the application of PGPR or Tri. +Humic acid significantly increased vegetative growth, yield and its components as well as chemical composition of tubers in both seasons compared with the control. Also, soil application as coating significantly increased all parameters of studied in both seasons compared to foliar application. In addition, cv. Red Sun significantly increasing all parameter than $\mathrm{cv}$. Sophie. In addition, the interaction between the $\mathrm{cv}$. Red Sun with coating application gave the highest values of all parameters. Also, interaction between cv. Red Sun with PGPR, Tri.+Humic acid and humic acid significantly increased all parameters of studied during both seasons. In this respect, the interaction between coating application and PGPR, Tri. +Humic acid and humic acid significantly increased all parameters of studied during both seasons.
\end{abstract}

Key words: Sandy soil, Coating, Foliar application, Bio and organic fertilizers, , Potatoes plants.

\section{INTRODUCTION}

Potato (Solanum tuberosum L.) is one of the most important vegetable crops grown in Egypt for local consumption and export. The variance between cultivars production depends on genetic characteristics, agriculture practices and the environmental conditions like organic and chemical fertilizers as well as water supply. Plant growth promoting rhizobacteria (PGPR) one of the bio fertilizers are a group of bacteria that actively strains isolated from plant roots and rhizosphere. Rhizosphere bacteria influence plant development and health directly and indirectly. Directly, by increase the availability of nutrients and indirectly by decrease the impact of plant pathogens. PGPR have many species as
Pseudomonas, Azospirillum, Azotobacter, Enterobacter, Arthobacter, Bacillus and Serratia reported to increase plant growth and yield (Ahmad et al., 2008). Many investigators studied the effect of PGPR and organic fertilizers. In this respect, Verma et al. (2013) indicated that when fertilizing with plant growth promoting rhizobacteria (PGPR) reduced the chemical fertilizers and increased the plant microbe interactions (Mesorhizobium sp. and PGPR) significantly enhanced the nodulation, plant growth, yield and uptake of $\mathrm{N}, \mathrm{P}$ and $\mathrm{Fe}$ and $\mathrm{N}$ fixation, also, the production of phytohormone (IAA) by microbial stimulated the growing plants, grain yield than the control at field of chickpea (Cicer arietinum L.). 
Trichoderma species are used as bio fertilizers and biological agent, enhance plant growth, antibiotics, defense to fungi and compete with plant microorganisms (Adams et al., 2007). Recently, several attempts have been undertaken to apply Trichoderma spp. as bio stimulants of seedling establishment, enhancement of plant growth and elicit plant defense (Shanmugaiah et al., 2009). T. harzianum may be used as alternative to the chemicals fungicides to suppress the wilt pathogen and raise the yield of tomato, improved chlorophyll content (Rasool et al., 2011). In the same direction (Carvajal et al., 2009) indicated that using some species of Trichoderma as promote plant growth, increased solubilization of macro and micro nutrients concentration which play a principle role in plant growth and indirectly with the control of the major and minor root infesting pathogens in rhizosphere, and improve nutrient uptake and plant defense level against biotic and/or a biotic stress.

Abbas et al. (2014) found that when added organic agriculture and good agricultural practices, rhizospheric micro organisms, bio propagates, bio fertilizer (bio fertile) and bio agent (bio control) increased both vegetative growth and tuber yields. Humic acid is a principal component of humic substances, humic substances are the final component of organic matter decomposition, which are the major organic constituent and its benefits in agricultural system are its ability to increase more moisture content, which increase water use efficiency in the amendment sandy soil, increased tubers yield quantity and quality and also increased solubilization of macro and micro nutrients concentration in soil and uptake by plants (Mosa, 2012; Selim et al., 2009; Suganya and Sivasamy,2006).

Paul et al. (2016) found that when added FYM at 10 ton/ ha. + chemical fertilizers as recommended dose + microbial consortia during summer seasons of five years increased vegetative growth, yield components, marketable yield, large tuber $(>75 \mathrm{~g})$, NPK uptake, available NPK and soil microbiological properties.

Many researchers studied the method of application for humic acid and organic fertilizers. In this connection, Zayed(2012) found that when planted Moringa seeds and treated with microorganisms using three methods of inoculation such as, soil inoculation (single or mixed cultures), leaf inoculation (single culture), and soil and leaf inoculation (mixed inoculation). All bio fertilization and inoculation methods gave highest recorded data for parameters under tested. Vegetative growth and vitamin C contents were obtained by using soil inoculation and mixed cultures of (Azot. chroococcum and Saccharomyces cerevisiae) and (Azot. Chroococcum and B. scirculans), the high content of protein, $\mathrm{Mg}$, $\mathrm{P}, \mathrm{K}, \mathrm{Zn}, \mathrm{Mn}, \mathrm{Fe}$ and $\mathrm{Cu}$ in leaves were obtained with different inoculation. Suh et al. (2014) found that no significant difference when potato plants treated with fulvic acid as a foliar application or humic acid as a soil application on the yield and quality of potato tubers (cv. Atlantic). Hegazi and Algharib (2014) found that applying compost tea as soil drench was better than as a foliar application in all parameter of experiments, i.e., vegetative growth, seed yield, seed quality and mineral content of cowpea seeds. The best results were obtained when added compost tea as soil drench and a foliar application spray at rate of $25 \%$ NPK $+75 \%$ compost tea. Also, Sania (2014) found that, foliar application of humic acid at rate of $2 \%$ significantly gave the highest plant height than the control treatment of canola spring cv.RGS-003, also, decreased nitrogen application in soil.

Therefore, the objective of this study was to investigate the effect of different seven treatments of organic and bio fertilizers adding as two types of application as coating for tubers and foliar application on vegetative growth characteristics, yield and its components as well as chemical 
composition of two potato tubers grown under sandy soil conditions.

\section{MATERIALS AND METHODS}

Two field experiments were carried out during the two summer growing seasons of 2014 and 2015 at the Experimental Farm of Environmental Studies and Research, Institute, Sadat City University to study the effect of different treatments of organic and bio fertilizers( control, Tricoderma, PGPR , humic acid, Tri. + PGPR, Tri. + humic acid and Tri. + PGPR + humic acid ) added as two types of application as coating and foliar application on vegetative growth characteristics, yield and its components as well as chemical composition of two potato cultivars tubers i.e., Red Sun and Sophie cultivated under sandy soil conditions.

Surface $(0-20 \mathrm{~cm})$ soil samples of the tested soil were token and analyzed for some physical and chemical properties, following the standard methods stated by Cottenie et al. (1982), and Klute (1986), and the data are presented in Table 1.

\section{Plan of Work:}

The experiments were conducted in sandy soil. The soil was prepared by ploughing, settlement and creation the soil. The Experimental area was divided into 84 plots, the area of each plot ( 3 rows $\times 3 \mathrm{~m}$ ), 7 treatments with three replicates in spilt- spilt plots in a randomized complete blocks design. The cultivars were situated in the main plots, while method of applications in subplots and organic and bio fertilizers in sub- sub plots. Two potato cultivars commonly planted in Egypt, Red Sun, and Sophie were cultivated on $16^{\text {th }}$ of January in two investigated seasons and spaced at 25 $\mathrm{cm}$ apart. The normal agriculture practices for growing potato plants were applied whenever required.

\section{Preparation of the biofertilizers}

The strains were used as plant growth promoting rizobacteria (PGPR), Azospirillum, Azotobacter, and Serratia were pre-cultured on nutrient agar media, then grown in a nutrient broth liquid medium for 2 days at $30^{\circ} \mathrm{C}$. The suspended cultures were then centrifugated at $1000 \mathrm{rpm}$ for $30 \mathrm{~min}$., at $10^{\circ} \mathrm{C}$. The sediment was re-suspended in 5 $\mathrm{ml}$ sterilized $0.8 \% \mathrm{KCl}$ solution $(\mathrm{w} / \mathrm{v})$. The bacterial suspension was again shaken for 5 min. Collins and Lyne (1980). These suspensions were introduced as bio fertilizer inoculants. Fungal preparation, $T$. harzianum strain local isolate .Cell suspensions of $T$. harzianum prepared by culturing the fungus in Czapek broth medium at $25^{\circ} \mathrm{C}$ for 7 days. The resulting culture was filtered through cheesecloth to separate mycelia fragments, washed by centrifugation (10,000 rpm for $15 \mathrm{~min})$.

Two application method was used for inoculation Trichoderma and PGPR, the first application coating potato tubers by dipping tubers into bacterial or fungal suspension for $30 \mathrm{~min}$. before planting or sowing and the second method of application was foliar on plant growth, while humic acid add with tubers before planting.

Table 1: Some physical and chemical analyses of the experimental soil.

\begin{tabular}{|c|c|c|c|c|c|c|c|c|c|c|}
\hline Location of soils & $\mathrm{PH}(\mathrm{KCl})$ & $\begin{array}{c}\mathrm{EC} \\
\mathrm{dS} . \mathrm{m}^{-1}\end{array}$ & $\begin{array}{c}\mathrm{OM} \\
\%\end{array}$ & $\begin{array}{c}\mathrm{CaCO}_{3} \\
\%\end{array}$ & $\begin{array}{c}\mathrm{CEC} \\
\mathrm{cmolc} . \\
\mathrm{Kg}^{-1}\end{array}$ & $\begin{array}{c}\text { Sand } \\
\%\end{array}$ & $\begin{array}{c}\text { Silt } \\
\%\end{array}$ & $\begin{array}{c}\text { Clay } \\
\%\end{array}$ & $\begin{array}{c}\text { Texture } \\
\text { Grade }\end{array}$ \\
\hline Sadat City & 7.39 & 1.82 & 0.36 & 5 & \multicolumn{2}{c|}{13.9} & 72.79 & 19.35 & 7.69 & Sandy loam \\
\hline Materials & $\mathrm{PH}$ & $\begin{array}{c}\mathrm{CTotal} \\
\%\end{array}$ & $\begin{array}{c}\mathrm{N} \\
\mathrm{ppm}\end{array}$ & $\begin{array}{c}\mathrm{P} \\
\mathrm{ppm}\end{array}$ & $\begin{array}{c}\mathrm{K} \\
\mathrm{ppm}\end{array}$ & $\begin{array}{c}\mathrm{Fe} \\
\mathrm{ppm}\end{array}$ & $\begin{array}{c}\mathrm{Mn} \\
\mathrm{ppm}\end{array}$ & $\begin{array}{c}\mathrm{Zn} \\
\mathrm{Ppm}\end{array}$ & $\begin{array}{c}\mathrm{Cu} \\
\mathrm{ppm}\end{array}$ \\
\hline $\begin{array}{c}\text { Soil (available } \\
\text { nutrient) }\end{array}$ & 7.39 & 0.22 & 11.10 & 6.83 & 280 & 14.98 & 3.01 & 1.82 & 1.01 \\
\hline
\end{tabular}




\section{Data recorded}

I) Vegetative growth measurements:

Five plants from each treatment were randomly pulled up at 70 days after planting to determine the plant height, number of main stems/ plant as well as fresh weight for plant.

\section{II) Total yield and tuber quality:}

After 120 days of planting, tubers from each plot were harvested, weighted and counted for recording, the average weight of tuber, average yield of tubers/ plant, total yield/ plot and then calculated as ton / fedden.

\section{Dry matter percentage:}

One hundred grams of fresh tubers were dried at $70 \mathrm{C}^{\circ}$ and $\mathrm{DM} \%$ was calculated.

\section{III) Chemical composition of potato tubers:-}

Mineral elements, i.e., macro and micro nutrients were determined by using ICP-MS.

Tubers were dried at $70 \mathrm{C}^{\circ}$ then grinded and digest one gram in sulfuric and percloric acids and filtered through disposable $0.2 \mu \mathrm{m}$ PTFE syringe filters (DISMIC25HP,Advantec, Tokyo, Japan).The metal concentrations in these extracts were determined by means of inductively coupled plasma-mass spectroscopy (ICP-MS) (ICA, Thermo, Germany). Certified reference materials (Merck, Germany) were included in the analyses. The recovery of metals was within the certified limits. Qtegra software was used for average and relative standard deviation calculation (Lambers et al., 2008), Calculation:(Standard curve was prepared by plotting absorbance reading against phosphorus concentrations, compute sample concentration by comparing sample absorbance with standard curve (APHA, 2005).

\section{Statistical analysis:-}

All recorded data were subjected to ANOVA to identify significant treatments and/ or interaction effects by ' $F$ test' using the SAS program (SAS Systems for Windows, release 9.1, SAS, 2003, Institute, Cary, NC). Mean separation between the significant treatments was calculated by L.S.D. at $0.05 \%$.

\section{RESULTS AND DISCUSSION I- Vegetative growth:-}

Data recorded in Table 2 show that, all the studied growth aspects i.e., plant height, number of branches and fresh weight/plant were significantly affected with adding the organic and bio fertilizers compared with the control. In this respect, to the effect of cultivars, results in Table 2, reveal that there were significant differences in all parameters of vegetative growth among the tested cultivars. In this connection, the highest values of vegetative growth were recorded in case of cv. Red Sun compared with cv. Sophie. Such results are true during both seasons of experiments. In this connection, the differences in morphological aspects between the tested cultivars might be due to the variation in a genetic pool between the potato cultivars and also the environmental conditions such as, organic and chemical fertilizers as well as water supply. Similar results on potato were agreement with reported by Abbas et al. (2014) and Arafa et al. (2015).

It is also evident from, data in Table 2, that there were significant differences in all the studied growth traits as a result to method of application. In this concern, the highest values in plant height and fresh weight per plant were recorded when using coating method than foliar application, while, the number of branches /plant was not significantly affected between the two methods of application. Obtained results were similar in both seasons of study.

With regard, the highest values in all the studied growth measurements were recorded in case of using the humic acids compared with other treatments. In addition, the lowest values were recorded with control 
and using Tricoderma treatment. No significant differences were noticed in case of other treatments. Obtained results are true during both seasons of study. In this regard, the increasing effect of humic acids on plant vegetative growth may be due to the main role on availability of macro and micro elements for absorption and its effect on cells division and cell elongation as well as the physiological function of the cells which consequently affect plant growth. Also, humic substances comprise a major part of organic matter, and their influence on soil properties is well known and could be used to improve microbial activity. In addition, humic substances can directly affect root growth (Nardi et al., 2009), humic substances act in a very similar way to growth hormones. The mechanism of humic acid in promoting plant growth may increased the uptake of micro and macro nutrients and decrease absorbed a some toxic elements, also, increasing cell membrane permeability, oxygen uptake, respiration, photosynthesis, phosphate uptake and root cell elongation of plant growth factors (Masciandaro et al., 2002; Russo and Berlin 1990) these results are in agreement with those reported by Suganya and Sivasamy (2006), Selim et al. (2009) and Verma et al. (2013) on potato.

Concerning, the influence of the interaction between cultivars and method of applications, data in Table 2 show that also the cv. Red sun in combination with tuber coating method significantly produced the highest values of vegetative growth parameters than the interaction between $\mathrm{cv}$. Sophie with tuber coating method during both growing seasons. These results are in agree with those reported by Lal and Rana (2013) who found that, inoculation okra with, Tricoderma harzianum, T. viride, Gliocla diumviren and Aspergillus ochraceous as soil and seed treatment increased plant growth parameters (plant height, shoot, root fresh and dry weights), also, found that, soil treatment with $T$. harzianum was the most effective fungus in reducing nematode multiplication at the highest dose $(15 \mathrm{~g} / \mathrm{kg}$ soil than other fungus.

Regarding, the effect of the interaction between two potato cultivars and organic or bio fertilizers, the same data in Table 2 show clearly that the studied vegetative growth characteristics were significantly affected due to the interaction between the tested potato cultivars and treatments of bio fertilizers. In this connection, the highest values in vegetative growth were noticed in the case of adding humic acid or PGPR with cv. Red Sun than the control during both seasons of study.

As for the effects of the interaction between the method of application and bio fertilizers on vegetative growth and its attributes, results in Table 2 show that the highest values were obtained when using tuber coating combined with humic acid application and foliar spry method combined with using PGPR treatments, this is true during both seasons of study. These results are reported with, Selim et al. (2009), Paul et al. (2016)on potato, similar results are reported by Hegazi and Algharib(2014) they found that applying compost tea as soil drench was better than as a foliar application in all parameter of experiments, i.e. vegetative growth, seed yield, seed quality and mineral content of cowpea seeds. The best results were obtained when added compost tea as a soil drench and at rate $25 \% \mathrm{NPK}+75 \%$ compost tea gave better results than other treatments.

\section{2 - Yield and its components:-}

As for the effect between the two cultivars, data in Table 3 reveal that, cv. Red sun significantly reflected the highest values of total yield and its components, i.e., average tuber weight, tubers yield/ plant and total yield/ fed.. However, the highest values of dry matter \% were recorded in case of cv. Sophie compared with cv. Red Sun in both seasons. Such differences in total produced yield and its components among the tested cultivars are related to the differences in their vegetative growth vigor (Table,1) and the variation in a genetic pool between the two tested potato cultivars. These results are in agreement with those reported by Arafa et al. (2015) on potato. 
Table 2: Effect of cultivars, method of applications and Humic acid, plant growth promoting and their first degree interaction on some vegetative growth characteristics of potatoes plant during the two seasons

\begin{tabular}{|c|c|c|c|c|c|c|c|}
\hline & Seasons & & 2014 & & & 2015 & \\
\hline Character & $\begin{array}{l}\text { stics } \\
\text { Treatments }\end{array}$ & $\begin{array}{l}\text { Plant } \\
\text { height } \\
(\mathrm{cm})\end{array}$ & $\begin{array}{l}\text { No. of } \\
\text { branches } \\
\text { / plant }\end{array}$ & $\begin{array}{l}\text { Fresh } \\
\text { weight/ } \\
\text { plant } \\
\text { (g) }\end{array}$ & $\begin{array}{c}\text { Plant } \\
\text { height } \\
(\mathrm{cm})\end{array}$ & $\begin{array}{l}\text { No. of } \\
\text { branches } \\
\text { / plant }\end{array}$ & $\begin{array}{l}\text { Fresh } \\
\text { weight / } \\
\text { plant } \\
\text { (g) }\end{array}$ \\
\hline$\stackrel{\omega}{\sigma}$ & Red Sun & 45.96 & 2.41 & 131.32 & 48.11 & 2.59 & 136.96 \\
\hline$\stackrel{\infty}{\geq}$ & Sophie & 35.75 & 1.90 & 83.82 & 41.22 & 2.20 & 90.05 \\
\hline$\overline{\bar{J}}$ & L.S.D. at $0.05 \%$ & 0.62 & 0.22 & 1.26 & 0.66 & 0.26 & 1.32 \\
\hline ¿ & Coating & 41.57 & 2.27 & 109.60 & 45.74 & 2.54 & 118.30 \\
\hline$\overline{0} \frac{0}{\pi}$ & Foliar & 40.14 & 2.20 & 105.53 & 43.00 & 2.52 & 110.96 \\
\hline 옹 $\frac{.0}{0}$ & L.S.D. at $0.05 \%$ & 0.62 & n.s & 1.26 & 0.72 & n.s & 1.35 \\
\hline & Control & 36.25 & 2.25 & 91.12 & 40.02 & 2.46 & 98.73 \\
\hline & Tricoderma & 37.12 & 2.22 & 89.75 & 42.38 & 2.43 & 98.75 \\
\hline$\stackrel{\text { On }}{ \pm}$ & PGPR & 43.25 & 2.37 & 108.12 & 46.14 & 2.55 & 116.44 \\
\hline$\stackrel{\bar{\varepsilon}}{E}$ & Humic acid & $45 . .55$ & 2.25 & 128.00 & 49.06 & 2.60 & 137.40 \\
\hline 觇 & Tri. + PGPR & 41.00 & 2.35 & 114.12 & 45.38 & 2.49 & 121.88 \\
\hline$\stackrel{\varrho}{\Perp}$ & Tri. +Humic acid & 41.00 & 2.18 & 98.37 & 43.68 & 2.45 & 105.45 \\
\hline & Tri. + PGPR+ Humic & 41.80 & 1.81 & 123.50 & 45.00 & 2.28 & 120.88 \\
\hline & L.S.D. at $0.05 \%$ & 1.16 & 0.46 & 2.37 & 1.22 & 0.50 & 2.41 \\
\hline Red Sun & Coating & 46.95 & 2.43 & 131.32 & 46.95 & 2.59 & 131.32 \\
\hline & Foliar & 45.43 & 2.39 & 130.50 & 45.43 & 2.39 & 130.50 \\
\hline Sonbir & Coating & 34.64 & 2.10 & 87.07 & 34.64 & 2.10 & 87.07 \\
\hline Sophie & Foliar & 36.85 & 2.01 & 80.57 & 36.85 & 2.010 & 80.57 \\
\hline & L.S.D. at $0.05 \%$ & 0.88 & 0.35 & 1.79 & 0.88 & 0.35 & 1.79 \\
\hline & Control & 40.00 & 2.50 & 110.5 & 42.50 & 2.70 & 115.5 \\
\hline & Tricoderma & 38.25 & 2.00 & 85.75 & 40.25 & 2.30 & 95.75 \\
\hline & PGPR & 49.50 & 2.75 & 151.00 & 51.55 & 2.95 & 159.00 \\
\hline Red Sun & Humic acid & 55.50 & 2.37 & 172.50 & 57.50 & 2.57 & 179.50 \\
\hline & Tri. + PGPR & 51.00 & 2.37 & 134.25 & 53.00 & 2.39 & 144.25 \\
\hline & Tri. +Humic acid & 39.25 & 2.50 & 101.75 & 41.50 & 2.70 & 111.75 \\
\hline & Tri. + PGPR+ Humic & 48.25 & 2.37 & 163.50 & 50.50 & 2.57 & 153.00 \\
\hline & Control & 32.50 & 2.00 & 71.75 & 36.75 & 2.15 & 80.75 \\
\hline & Tricoderma & 36.00 & 2.15 & 93.75 & 45.00 & 2.25 & 99.75 \\
\hline & PGPR & 37.75 & 2.00 & 65.25 & 41.75 & 2.05 & 70.50 \\
\hline Sophie & Humic acid & 34.75 & 2.03 & 84.50 & 38.75 & 2.50 & 90.57 \\
\hline & Tri. + PGPR & 31.00 & 2.05 & 93.00 & 40.00 & 2.25 & 99.00 \\
\hline & Tri. +Humic acid & 42.75 & 1.88 & 95.00 & 46.00 & 2.00 & 99.30 \\
\hline & Tri. + PGPR+ Humic & 35.50 & 1.25 & 83.50 & 40.50 & 2.20 & 90.50 \\
\hline & L.S.D. at $0.05 \%$ & 1.64 & 0.66 & 3.35 & 1.60 & 0.64 & 3.25 \\
\hline & Control & 33.00 & 1.88 & 87.50 & 37.50 & 1.98 & 97.90 \\
\hline & Tricoderma & 41.00 & 2.50 & 103.75 & 48.00 & 2.80 & 113.75 \\
\hline Coating & PGPR & 37.75 & 2.13 & 90.75 & 40.75 & 2.33 & 100.75 \\
\hline & Humic acid & 49.50 & 2.63 & 160.00 & 54.50 & 2.93 & 170.50 \\
\hline & Tri. + PGPR & 46.00 & 2.50 & 123.75 & 50.00 & 2.70 & 133.75 \\
\hline & Tri. +Humic acid & 40.75 & 2.25 & 103.50 & 42.95 & 2.55 & 110.50 \\
\hline & Tri. + PGPR+ Humic & 43.00 & 2.00 & 98.00 & 46.50 & 2.50 & 101.00 \\
\hline & Control & 36.00 & 2.50 & 94.75 & 38.50 & 2.70 & 100.75 \\
\hline & Tricoderma & 33.25 & 2.25 & 75.75 & 36.25 & 2.38 & 85.75 \\
\hline & PGPR & 48.00 & 2.63 & 125.50 & 50.50 & 2.90 & 135.50 \\
\hline Foliar & Humic acid & 42.50 & 2.00 & 95.00 & 45.50 & 2.50 & 105.00 \\
\hline & Tri. + PGPR & 39.50 & 2.63 & 105.50 & 43.50 & 2.83 & 110.50 \\
\hline & Tri. +Humic acid & 41.25 & 2.13 & 93.25 & 44.25 & 2.53 & 100.25 \\
\hline & Tri. + PGPR+ Humic & 40.50 & 1.63 & 149.00 & 42.50 & 1.83 & 139.00 \\
\hline & L.S.D. at $0.05 \%$ & 1.64 & 0.66 & 3.35 & 1.72 & 0.70 & 3.45 \\
\hline
\end{tabular}


Effect of humic acid, plant growth promoting and methods of ..................

Table 3: Effect of cultivars, method of applications and Humic acid, plant growth promoting and their first degree of interaction on yield and its components of potatoes during the two seasons.

\begin{tabular}{|c|c|c|c|c|c|c|c|c|c|}
\hline \multicolumn{2}{|r|}{ Seasons } & \multicolumn{4}{|c|}{2014} & \multicolumn{4}{|c|}{2015} \\
\hline Charact & Treatments & $\begin{array}{l}\text { Average } \\
\text { tuber } \\
\text { weight } \\
\text { (g) }\end{array}$ & $\begin{array}{l}\text { Tubers } \\
\text { yield/ } \\
\text { plant } \\
(\mathrm{kg})\end{array}$ & $\begin{array}{c}\text { Dry } \\
\text { weight } \\
\text { of tubers } \\
\%\end{array}$ & $\begin{array}{c}\text { Total } \\
\text { yield } \\
\text { ton/fed. }\end{array}$ & $\begin{array}{l}\text { Average } \\
\text { tuber } \\
\text { weight } \\
\text { (g) }\end{array}$ & $\begin{array}{l}\text { Tubers } \\
\text { yield/ } \\
\text { plant } \\
(\mathrm{kg})\end{array}$ & $\begin{array}{c}\text { Dry } \\
\text { weight } \\
\text { of tubers } \\
\%\end{array}$ & $\begin{array}{c}\text { Total } \\
\text { yield } \\
\text { ton/fed. }\end{array}$ \\
\hline$\frac{\infty}{\stackrel{\infty}{D}}$ & $\begin{array}{l}\text { Red Sun } \\
\text { Sophie } \\
\text { L.S.D. at } 0.05 \%\end{array}$ & $\begin{array}{c}121.82 \\
69.67 \\
1.12\end{array}$ & $\begin{array}{c}0.810 \\
0.331 \\
0.02\end{array}$ & $\begin{array}{c}16.21 \\
22.35 \\
2.03\end{array}$ & $\begin{array}{c}14.580 \\
5.820 \\
0.17\end{array}$ & $\begin{array}{l}79.85 \\
50.50 \\
2.65\end{array}$ & $\begin{array}{c}0.701 \\
0.494 \\
0.03\end{array}$ & $\begin{array}{c}15.88 \\
21.72 \\
2.00\end{array}$ & $\begin{array}{c}12.037 \\
8.531 \\
0.93\end{array}$ \\
\hline 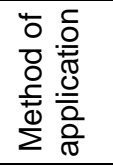 & $\begin{array}{l}\text { Coating } \\
\text { Foliar } \\
\text { L.S.D. at } 0.05 \%\end{array}$ & $\begin{array}{c}99.64 \\
91.85 \\
1.13\end{array}$ & $\begin{array}{c}0.522 \\
0.620 \\
0.01\end{array}$ & $\begin{array}{c}19.75 \\
18.82 \\
\text { n.s }\end{array}$ & $\begin{array}{c}11.055 \\
9.345 \\
0.17\end{array}$ & $\begin{array}{c}64.64 \\
65.64 \\
\text { n.s }\end{array}$ & $\begin{array}{c}0.659 \\
0.536 \\
0.03\end{array}$ & $\begin{array}{c}19.47 \\
18.62 \\
\text { n.s }\end{array}$ & $\begin{array}{c}11.468 \\
9.100 \\
0.92\end{array}$ \\
\hline 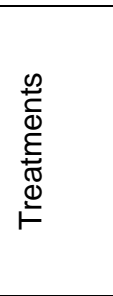 & $\begin{array}{l}\text { Control } \\
\text { Tricoderma } \\
\text { PGPR } \\
\text { Humic acid } \\
\text { Tri. + PGPR } \\
\text { Tri. +Humic acid } \\
\text { Tri. + PGPR+ Humic } \\
\text { L.S.D. at } 0.05 \%\end{array}$ & $\begin{array}{c}79.25 \\
85.00 \\
84.63 \\
102.88 \\
120.00 \\
106.75 \\
91.75 \\
2.11\end{array}$ & $\begin{array}{c}0.468 \\
0.598 \\
0.654 \\
0.584 \\
0.615 \\
0.535 \\
0.537 \\
0.02 \\
\end{array}$ & $\begin{array}{l}18.18 \\
19.82 \\
19.41 \\
20.17 \\
19.25 \\
19.83 \\
18.32 \\
0.70 \\
\end{array}$ & \begin{tabular}{|c|}
8.319 \\
10.759 \\
11.828 \\
10.450 \\
10.850 \\
9.598 \\
9.595 \\
0.32
\end{tabular} & $\begin{array}{l}60.75 \\
69.38 \\
63.88 \\
64.00 \\
61.88 \\
65.00 \\
71.38 \\
4.96\end{array}$ & $\begin{array}{l}0.498 \\
0.537 \\
0.625 \\
0.686 \\
0.644 \\
0.565 \\
0.626 \\
0.06 \\
\end{array}$ & $\begin{array}{l}18.82 \\
18.08 \\
19.25 \\
19.95 \\
18.52 \\
19.59 \\
18.04 \\
0.70\end{array}$ & $\begin{array}{c}8.678 \\
9.147 \\
10.219 \\
11.931 \\
11.205 \\
9.791 \\
11.016 \\
1.73\end{array}$ \\
\hline $\begin{array}{l}\text { Red } \\
\text { Sun }\end{array}$ & $\begin{array}{l}\text { Coating } \\
\text { Foliar }\end{array}$ & $\begin{array}{l}126.85 \\
116.79\end{array}$ & $\begin{array}{l}0.688 \\
0.931\end{array}$ & $\begin{array}{l}16.17 \\
16.25\end{array}$ & $\begin{array}{l}12.415 \\
16.743\end{array}$ & $\begin{array}{l}83.64 \\
76.07\end{array}$ & $\begin{array}{l}0.885 \\
0.518\end{array}$ & $\begin{array}{l}16.35 \\
16.01\end{array}$ & $\begin{array}{c}15.454 \\
8.621\end{array}$ \\
\hline Sophie & $\begin{array}{l}\text { Coating } \\
\text { Foliar } \\
\text { L.S.D. at } 0.05 \%\end{array}$ & $\begin{array}{c}72.43 \\
66.93 \\
1.60 \\
\end{array}$ & $\begin{array}{c}0.355 \\
0.307 \\
0.02 \\
\end{array}$ & $\begin{array}{c}23.33 \\
21.39 \\
0.53 \\
\end{array}$ & $\begin{array}{c}6.275 \\
5.365 \\
0.24\end{array}$ & $\begin{array}{c}53.21 \\
47.78 \\
3.75\end{array}$ & $\begin{array}{c}0.433 \\
0.554 \\
0.04\end{array}$ & $\begin{array}{c}23.00 \\
21.09 \\
0.43\end{array}$ & $\begin{array}{c}7.483 \\
9.580 \\
0.21\end{array}$ \\
\hline $\begin{array}{l}\text { Red } \\
\text { Sun }\end{array}$ & $\begin{array}{l}\text { Control } \\
\text { Tricoderma } \\
\text { PGPR } \\
\text { Humic acid } \\
\text { Tri. + PGPR } \\
\text { Tri. +Humic acid } \\
\text { Tri. + PGPR+ Humic }\end{array}$ & $\begin{array}{c}98.25 \\
101.75 \\
98.50 \\
152.00 \\
165.25 \\
128.75 \\
108.25 \\
\end{array}$ & $\begin{array}{l}0.624 \\
0.957 \\
0.847 \\
0.871 \\
0.793 \\
0.757 \\
0.818 \\
\end{array}$ & $\begin{array}{l}14.48 \\
16.95 \\
15.27 \\
17.96 \\
16.42 \\
16.95 \\
15.42 \\
\end{array}$ & $\begin{array}{l}11.195 \\
17.352 \\
15.337 \\
15.665 \\
14.106 \\
13.705 \\
14.693\end{array}$ & $\begin{array}{l}72.25 \\
78.75 \\
74.25 \\
82.00 \\
75.75 \\
83.00 \\
93.00 \\
\end{array}$ & $\begin{array}{l}0.580 \\
0.533 \\
0.719 \\
0.789 \\
0.854 \\
0.631 \\
0.803\end{array}$ & $\begin{array}{l}15.25 \\
14.95 \\
15.35 \\
17.55 \\
16.12 \\
16.75 \\
15.22\end{array}$ & $\begin{array}{c}10.033 \\
9.110 \\
11.300 \\
13.896 \\
15.063 \\
10.778 \\
14.083\end{array}$ \\
\hline Sophie & $\begin{array}{l}\text { Control } \\
\text { Tricoderma } \\
\text { PGPR } \\
\text { Humic acid } \\
\text { Tri. + PGPR } \\
\text { Tri. +Humic acid } \\
\text { Tri. + PGPR+ Humic } \\
\text { L.S.D. at } 0.05 \%\end{array}$ & $\begin{array}{l}60.25 \\
68.25 \\
70.75 \\
53.75 \\
74.75 \\
84.75 \\
75.25 \\
2.10\end{array}$ & $\begin{array}{c}0.311 \\
0.240 \\
0.460 \\
0.298 \\
0.438 \\
0.314 \\
0.258 \\
0.04\end{array}$ & $\begin{array}{l}21.87 \\
22.68 \\
23.56 \\
22.38 \\
22.07 \\
22.71 \\
21.21 \\
0.99\end{array}$ & $\begin{array}{l}5.443 \\
4.166 \\
8.318 \\
5.236 \\
7.594 \\
5.490 \\
4.496 \\
0.451\end{array}$ & $\begin{array}{l}49.25 \\
60.00 \\
53.50 \\
46.00 \\
48.00 \\
47.00 \\
49.75 \\
7.02\end{array}$ & $\begin{array}{c}0.415 \\
0.540 \\
0.531 \\
0.584 \\
0.435 \\
0.500 \\
0.450 \\
0.08\end{array}$ & $\begin{array}{c}22.00 \\
21.25 \\
23.25 \\
22.15 \\
19.77 \\
22.41 \\
21.18 \\
0.89\end{array}$ & $\begin{array}{c}7.325 \\
9.184 \\
9.139 \\
9.968 \\
7.349 \\
8.806 \\
7.950 \\
0.40\end{array}$ \\
\hline Coating & $\begin{array}{l}\text { Control } \\
\text { Tricoderma } \\
\text { PGPR } \\
\text { Humic acid } \\
\text { Tri. + PGPR } \\
\text { Tri. +Humic acid } \\
\text { Tri. + PGPR+ Humic }\end{array}$ & $\begin{array}{c}82.75 \\
87.50 \\
85.00 \\
80.00 \\
153.00 \\
117.25 \\
92.00\end{array}$ & $\begin{array}{l}0.463 \\
0.546 \\
0.505 \\
0.525 \\
0.591 \\
0.464 \\
0.556\end{array}$ & $\begin{array}{l}18.28 \\
20.54 \\
19.64 \\
21.29 \\
20.33 \\
20.28 \\
17.86 \\
\end{array}$ & \begin{tabular}{|c|}
8.395 \\
11.888 \\
14.408 \\
11.707 \\
11.088 \\
10.810 \\
10.106
\end{tabular} & $\begin{array}{l}61.50 \\
66.25 \\
58.00 \\
55.50 \\
69.00 \\
67.25 \\
75.00\end{array}$ & $\begin{array}{l}0.445 \\
0.540 \\
0.664 \\
0.737 \\
0.757 \\
0.718 \\
0.751\end{array}$ & $\begin{array}{l}19.04 \\
18.11 \\
19.31 \\
21.09 \\
20.10 \\
20.10 \\
17.70\end{array}$ & $\begin{array}{c}5.348 \\
9.148 \\
11.381 \\
12.811 \\
13.585 \\
12.558 \\
13.199\end{array}$ \\
\hline Foliar & $\begin{array}{l}\text { Control } \\
\text { Tricoderma } \\
\text { PGPR } \\
\text { Humic acid } \\
\text { Tri. + PGPR } \\
\text { Tri. +Humic acid } \\
\text { Tri. + PGPR+ Humic } \\
\text { L.S.D. at } 0.05 \% \\
\end{array}$ & $\begin{array}{c}75.75 \\
82.50 \\
84.25 \\
125.75 \\
87.00 \\
96.25 \\
91.00 \\
2.98 \\
\end{array}$ & $\begin{array}{c}0.473 \\
0.650 \\
0.801 \\
0.644 \\
0.639 \\
0.608 \\
0.556 \\
0.04 \\
\end{array}$ & $\begin{array}{l}18.09 \\
19.08 \\
19.19 \\
19.05 \\
18.16 \\
19.38 \\
18.77 \\
0.98 \\
\end{array}$ & \begin{tabular}{c|}
8.242 \\
9.630 \\
9.248 \\
9.194 \\
10.611 \\
8.385 \\
10.106 \\
0.45 \\
\end{tabular} & $\begin{array}{l}60.00 \\
72.50 \\
69.75 \\
72.50 \\
54.75 \\
62.25 \\
67.75 \\
7.02 \\
\end{array}$ & $\begin{array}{c}0.551 \\
0.535 \\
0.586 \\
0.635 \\
0.531 \\
0.413 \\
0.501 \\
0.08 \\
\end{array}$ & $\begin{array}{l}19.00 \\
18.00 \\
19.10 \\
19.00 \\
18.10 \\
19.08 \\
18.07 \\
0.96 \\
\end{array}$ & $\begin{array}{c}7.510 \\
9.146 \\
9.058 \\
11.053 \\
8.826 \\
7.026 \\
8.834 \\
0.39 \\
\end{array}$ \\
\hline
\end{tabular}


Concerning, the influence for method of application, the same data in Table 3 detect also that, the coating method application significantly increased most of yield parameters i.e., average tuber weight during the first season, yield/ plant and total yield / fed. during the first and second seasons gave the highest values than foliar application, while, average tuber yield during the second season and dry matter content of tubers during both seasons had no difference between both two methods of application. These results agree with those reported by Hegazi and Algharib (2014) they found that applying compost tea as soil drench was better than as a foliar application in all parameter of yield, i.e. seed yield, seed quality and mineral content of cowpea seeds.

Data in Table 3 show that all parameters of total yield and its components expressed as average tuber weight, tubers yield/ plant, dry matter content of tubers and total yield/ fed., were significantly increased with applied organic and bio fertilizers, in this concern, the treatments of bio fertilizers i.e., PGPR, humic acid, Tricoderma+PGPR and Tri.+humic acid gave the highest values in all parameters of yield and its components, during both seasons of 2014 and 2015 respectively.

The response of yield and its components for applications of humic acid was connected with its affect on vegetative growth Table 2 play an important role in increasing plant resistance against common potato diseases, increase both quantity and quality characteristics of tubers, and improve quality and soil fertility (Mosa,2012). These results are in agreement with this reported by Selim et al. (2009), Abbas et al. (2014) and Paul et al. (2016) on potato. Similar results are confirmed by Verma et al.(2013) indicated that adding (PGPR) for chickpea (Cicer arietinum L.) plants reduced the chemical fertilizers in agriculture and increased the plant-microbe interactions, also Mesorhizobium sp. and PGPR were significantly better for nodulation, plant growth, yield and uptake of $\mathrm{N}, \mathrm{P}$ and $\mathrm{Fe}$, enhanced the nodulation and $\mathrm{N}$ fixation, also, the production of phytohormone (IAA) by microbial stimulated the growth of plants and grain yield than the control. On the other hand, Suh et al. (2014) They found that no significant effect on tuber size, total yield or other chemical compositions of tubers when added humic acid as soil application before planting.

Concerning, the influence of the interaction between cvs. and method of applications, data in Table 3 show that cv. Red sun in combination with coating method significantly produced the highest values of total produced yield and its components except for dry matter content \%, the interaction between cv. Sophie with tuber coating method recorded the highest values than Cv. Red sun during both growing seasons.

The same data in Table 3 indicate that, the interaction between cvs. and treatments of organic and bio fertilizers, illustrate that cv. Red Sun in combination with Tricoderma, Humic acid, Tri. + PGPR and Tri. + PGPR+ Humic acid gave the highest parameters of yield under these study, except dry matter content $\%$ of tubers, data show that the interaction between cv. Sophie with Humic acid, Tri. or PGPR treatments recorded the highest values than cv. Red sun, this is true during both seasons of experiments, these results are in agreement with (Hicks et al., 2014) investigate the suppression of Rhizoconia diseases and promoting the growth of potato plants by Tricoderma strains. They found that, the greatest proportional increases for three plant growth parameters compared with the control by: T. harzianum LU1491 (number of tubers), T. barbatum LU1489 (total tuber weight), and Trichoderma spp. 792 LU1483 (average tuber weight). Trichoderma atrovirideLU144 had positive 
impacts on several Rhizoctonia disease and plant growth parameters, combinations of two Trichoderma strains increased potato tuber yields and suppress Rhizoctonia diseases of potato.

In the same direction, data in Table 3 show that the interaction between methods of application and organic and bio fertilizers. Data indicat that, the treatments of PGPR, Humic acid, Tri. + PGPR and Tri. + PGPR+ Humic acid as coating method gave the highest values than other treatments in this respect during both seasons of 2014 and 2015. These results agree with Abbas et al. (2014) on potato and Hegazi and Algharib (2014) on cowpea.

\section{3- Chemical composition of potato tubers:-}

The effect of differences between the two cultivars of potato on the chemical composition of potato tubers, data in Tables, 4 \& 5 indicate that, no differences between two cvs. on chemical composition of tubers contents ( $\mathrm{N}, \mathrm{P}, \mathrm{K}, \mathrm{Fe}, \mathrm{Mn}$ and $\mathrm{Zn}$ ) in this respect during both seasons of studying .

AS for the effect of application methods, data in Tables, $4 \& 5$ show that the two methods of application (coating and foliar) had no significant effect between them on chemical composition of tubers contents ( $N$, $\mathrm{P}, \mathrm{K}, \mathrm{Fe}, \mathrm{Mn}$ and $\mathrm{Zn}$ ), during both seasons of study.

Influence of organic and bio fertilizers application, on the chemical composition ( $N$, $\mathrm{P}, \mathrm{K}, \mathrm{Fe}, \mathrm{Mn}$ and $\mathrm{Zn}$ ) of potato tubers, data in Tables $4 \& 5$ indicate that applying the PGPR, humic acid, Tricoderma + PGPR and Tri.+humic acid significantly gave the highest values in chemical composition of potato tubers, during both season of experiments. Such results are confirmed with those reported by (Paul et al., 2016; Selim et al., 2009; Suganya and Sivasamy, 2006) all working on potato and indicated that adding humic acid and microbial groups individual or in combinations increased NPK uptake in tubers, and available NPK and microbiological properties in soil. These results are in a good harmony with (Aiken et al., 1985) indicated that, the role of humic substances application is mainly related to the increased nutrients uptake, increases soil cation exchange capacity (ability and release cations such as $\left(\mathrm{K}^{+}, \mathrm{Ca}^{++}\right.$, or $\left.\mathrm{NH}_{4}{ }^{+}\right)$, and can also form complexes with micronutrients.

Regarding the effect of the interaction between the two cultivars of potato and methods of application (coating and foliar) on the chemical composition of potato tubers, data in Tables, $4 \& 5$ indicate that, the $\mathrm{cv}$. Red sun in combination with method of application as coating significantly gave the highest values during both seasons.

Concerning the influence of the interaction between cvs. and treatment of applications, data in Tables, 4 \& 5 illustrates that Cv. Red Sun in combination with Tricoderma, Humic acid, PGPR and Tri. + Humic acid gave the highest values of chemical composition of potato tubers ( $N, P$, $\mathrm{K}, \mathrm{Fe}, \mathrm{Mn}$ and $\mathrm{Zn}$ ) content, this is true during both seasons of 2014 and 2015.

Regarding the effect of the interaction between the two methods of application (coating and foliar application) and treatments of organic and bio fertilizers on the chemical composition of potato tubers, data in Tables, 4 \& 5 indicate that, the coating application in combination with Tricoderma, Humic acid, PGPR, Tri. + PGPR and Tri. + Humic acid gave the highest values of chemical composition of potato tubers ( $\mathrm{N}, \mathrm{P}, \mathrm{K}, \mathrm{Fe}, \mathrm{Mn}$ and $\mathrm{Zn}$ ) content. This is true during both seasons of 2014 and 2015. These results are in a good harmony with Hegazi and Algharib(2014)on cowpea, they found that applying compost tea as soil drench was better than as a foliar application in mineral content of cowpea seeds. Similar results are obtained by Zayed (2012) found that using three methods of inoculation microorganisms gave the highest 
Table 4: Effect of cultivars, methods of applications and Humic acid, Plant growth promoting and their first degree of interaction on potato chemical composition during the two seasons.

\begin{tabular}{|c|c|c|c|c|c|c|c|}
\hline \multirow{2}{*}{\multicolumn{2}{|c|}{$\begin{array}{c}\text { Seasons } \\
\text { Characteristics } \\
\text { Treatments }\end{array}$}} & \multicolumn{6}{|c|}{2014} \\
\hline & & $\begin{array}{c}\mathrm{N} \\
\mathrm{ppm}\end{array}$ & $\begin{array}{c}\mathrm{P} \\
\mathrm{ppm}\end{array}$ & $\begin{array}{c}\mathrm{K} \\
\mathrm{ppm}\end{array}$ & $\begin{array}{c}\mathrm{Fe} \\
\mathrm{ppm}\end{array}$ & $\begin{array}{c}\mathrm{Mn} \\
\mathrm{ppm}\end{array}$ & $\begin{array}{c}\mathrm{Zn} \\
\mathrm{ppm}\end{array}$ \\
\hline \multirow{3}{*}{ 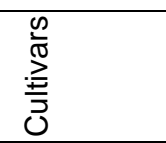 } & Red Sun & 2.16 & 0.282 & 14.55 & 1.37 & 17.08 & 8.42 \\
\hline & Sophie & 1.27 & 0.271 & 12.34 & 1.21 & 16.39 & 5.93 \\
\hline & L.S.D. at $0.05 \%$ & n.s & n.s & n.s & n.s & n.s & n.s \\
\hline \multirow{3}{*}{ 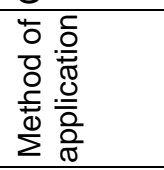 } & Coating & 2.06 & 0.296 & 14.79 & 1.36 & 16.69 & 10.43 \\
\hline & Foliar & 1.39 & 0.257 & 12.09 & 1.22 & 16.58 & 3.79 \\
\hline & L.S.D. at $0.05 \%$ & n.s & n.s & n.s & n.s & n.s & n.s \\
\hline \multirow{8}{*}{ 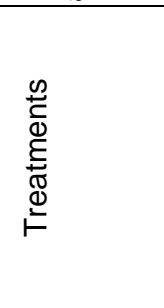 } & Control & 1.27 & 0.245 & 12.93 & 1.06 & 16.33 & 6.71 \\
\hline & Tricoderma & 1.96 & 0.284 & 14.08 & 1.24 & 16.31 & 7.91 \\
\hline & PGPR & 2.33 & 0.296 & 13.30 & 1.28 & 17.00 & 6.82 \\
\hline & Humic acid & 1.33 & 0.283 & 13.39 & 1.33 & 17.24 & 7.42 \\
\hline & Tri. + PGPR & 1.62 & 0.306 & 13.83 & 1.24 & 16.48 & 7.45 \\
\hline & Tri. +Humic acid & 1.56 & 0.249 & 13.19 & 1.52 & 16.35 & 6.74 \\
\hline & Tri. + PGPR+ Humic & 1.98 & 0.272 & 13.37 & 1.36 & 16.74 & 6.95 \\
\hline & L.S.D. at $0.05 \%$ & 1.10 & 0.31 & 1.14 & 0.30 & 1.20 & 1.61 \\
\hline \multirow{2}{*}{ Red Sun } & Coating & 2.84 & 0.322 & 17.25 & 1.64 & 18.33 & 13.35 \\
\hline & Foliar & 1.54 & 0.243 & 12.11 & 1.11 & 17.75 & 3.79 \\
\hline \multirow{3}{*}{ Sophie } & Coating & 1.28 & 0.269 & 12.88 & 1.09 & 15.04 & 8.35 \\
\hline & Foliar & 1.56 & 0.272 & 12.04 & 1.33 & 15.84 & 3.79 \\
\hline & L.S.D. at $0.05 \%$ & 0.83 & 0.24 & 0.85 & 0.22 & 0.90 & 1.22 \\
\hline \multirow{6}{*}{ Red Sun } & Control & 1.82 & 0.291 & 13.75 & 1.15 & 16.55 & 7.15 \\
\hline & Tricoderma & 2.79 & 0.587 & 15.63 & 1.40 & 15.50 & 10.15 \\
\hline & PGPR & 3.37 & 0.263 & 15.23 & 1.65 & 16.13 & 8.60 \\
\hline & Humic acid & 1.06 & 0.330 & 13.85 & 1.58 & 18.75 & 8.70 \\
\hline & Tri. + PGPR & 1.95 & 0.318 & 14.48 & 1.35 & 16.93 & 8.65 \\
\hline & Tri. +Humic acid & 1.68 & 0.257 & 14.20 & 1.85 & 16.08 & 7.50 \\
\hline \multirow{9}{*}{ Sophie } & Tri. + PGPR+ Humic & 2.45 & 0.238 & 14.68 & 1.25 & 17.85 & 8.25 \\
\hline & Control & 0.71 & 0.253 & 12.10 & 0.98 & 16.03 & 6.28 \\
\hline & Tricoderma & 1.13 & 0.281 & 12.53 & 1.08 & 17.13 & 5.68 \\
\hline & PGPR & 1.28 & 0.323 & 11.38 & 0.93 & 17.88 & 5.05 \\
\hline & Humic acid & 1.25 & 0.242 & 12.93 & 1.10 & 15.73 & 6.15 \\
\hline & Tri. + PGPR & 1.61 & 0.294 & 13.18 & 1.13 & 16.03 & 6.75 \\
\hline & Tri. +Humic acid & 1.44 & 0.241 & 12.18 & 1.53 & 16.63 & 5.98 \\
\hline & Tri. + PGPR+ Humic & 1.50 & 0.252 & 12.18 & 1.48 & 15.63 & 5.65 \\
\hline & L.S.D. at $0.05 \%$ & 1.55 & 0.44 & 1.60 & 0.43 & 1.70 & 2.28 \\
\hline \multirow{6}{*}{ Coating } & Control & 0.65 & 0.286 & 13.38 & 1.10 & 16.73 & 9.90 \\
\hline & Tricoderma & 2.50 & 0.301 & 16.48 & 1.40 & 15.10 & 11.70 \\
\hline & PGPR & 3.70 & 0.334 & 14.95 & 1.65 & 16.58 & 9.73 \\
\hline & Humic acid & 1.04 & 0.322 & 15.38 & 1.43 & 16.95 & 11.08 \\
\hline & Tri. + PGPR & 1.39 & 0.347 & 15.23 & 1.28 & 16.60 & 10.22 \\
\hline & Tri. +Humic acid & 2.10 & 0.246 & 13.53 & 1.43 & 17.52 & 10.03 \\
\hline \multirow{9}{*}{ Foliar } & Tri. + PGPR+ Humic & 3.02 & 0.233 & 14.57 & 1.38 & 17.40 & 10.35 \\
\hline & Control & 1.36 & 0.258 & 11.80 & 1.03 & 16.00 & 3.53 \\
\hline & Tricoderma & 1.42 & 0.267 & 11.68 & 1.07 & 17.42 & 4.13 \\
\hline & PGPR & 1.05 & 0.259 & 11.65 & 1.03 & 17.42 & 3.93 \\
\hline & Humic acid & 1.88 & 0.244 & 11.40 & 1.25 & 17.52 & 3.78 \\
\hline & Tri. + PGPR & 1.90 & 0.264 & 12.43 & 1.20 & 15.65 & 4.18 \\
\hline & Tri. +Humic acid & 1.02 & 0.252 & 12.48 & 1.55 & 16.10 & 3.45 \\
\hline & Tri. + PGPR+ Humic & 0.94 & 0.257 & 13.22 & 1.35 & 15.95 & 3.55 \\
\hline & L.S.D. at $0.05 \%$ & 1.55 & 0.44 & 1.60 & 0.43 & 1.70 & 2.28 \\
\hline
\end{tabular}


Effect of humic acid, plant growth promoting and methods of ..................

Table 5: Effect of cultivars, method of applications and Humic acid, Plant growth promoting and their first degree of interaction on potato chemical composition during the two seasons.

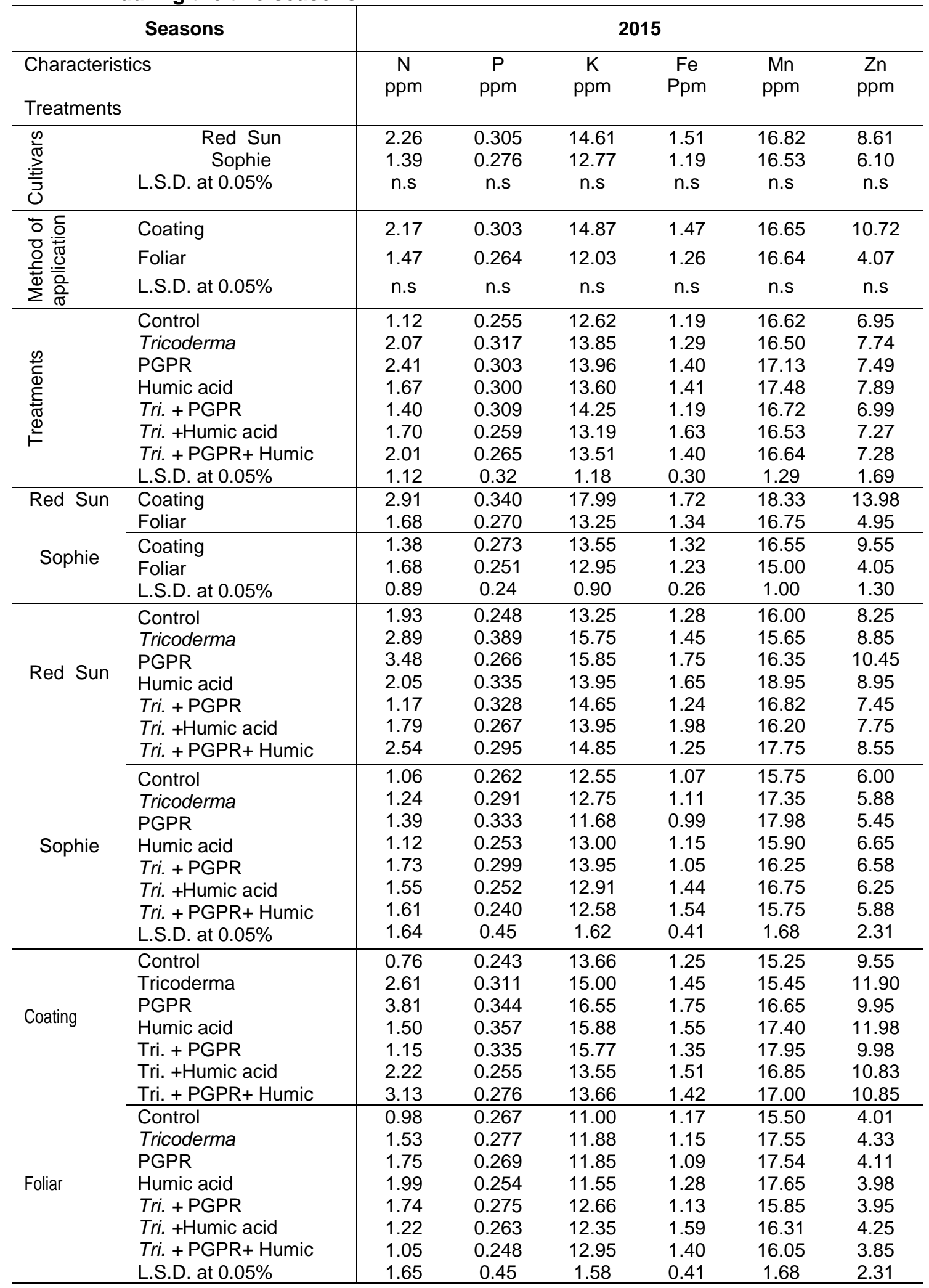


protein contents, vitamin $\mathrm{C}$ in leaves were obtained with soil inoculation single or mixed cultures and gave the highest records of $\mathrm{Mg}$, $\mathrm{P}, \mathrm{K}, \mathrm{Zn}, \mathrm{Mn}, \mathrm{Fe}$ and $\mathrm{Cu}$ contents in leaves of Moringa plants. Similar results were confirmed with Verma et al. (2013) indicated that use of plant growth promoting rhizobacteria (PGPR)on chickpea plants increased uptake of N,P and Fe contents of seeds. On the other hand, Suh et al. (2014) found that no significant differences in chemical composition of potato tubers when treated with fulvic acid and humic acids, also soil application of humic acid had no effect on chemical compositions of potato tubers.

Finally, it can be concluded that, planting potato Red Sun cultivar with using organic and bio fertilizers, humic acid and micro organism like PGPR, and Tricoderma as tuber coating method gave the highest production of vegetative growth, yield and its components and chemical composition of tubers grown under sandy soil condition and suitable with the Egyptians environmental conditions.

\section{REFERENCES}

Abbas, M. T., M. A. Hamza, H. H. Youssef, G. H. Youssef, M. Fayez, M. Monib and N. A. Hegazi (2014). Bio-preparates support the productivity of potato plants grown under desert farming conditions of north Sinai: Five years of field trials. Journal of Advanced Research 5, 41-48.

Adams, P., D.L. FAAM and J.M. Lynch (2007). Trichoderma hrzianum Rifai129522 mediates growth promotion of crack willow (Salix fragilis) saplings in both clean and metal- contaminated soil. Microbiology Ecology 54:306-313.

Ahmad, F., I. Ahmad and M.S. Khan (2008). Screening of free-living rhizospheric bacteria for their multiple plant growth promoting activities. Microbiological Research 163: 173-181.

Aiken, G.R., D.M. McKnight, R.L. Wershaw and P. MacCarthy (1985). Humic Substances in Soil, Sediment and Water. Wiley-Inter science, New York.
American Public Health Association [APHA] (2005). Standard Methods for the Examination of Water and Wastewater $22^{\text {nd }}$ ed. APHA, Inc. Washington, D.C.

Arafa, M. M., W. M. Darwisch and N. Elhefnawy (2015). Effect of deficit irrigation on vegetative growth, yield and quality of two potato cultivars under sandy soil conditions. Journal Plant Production, Mansoura University, 6(11):1845-1860.

Black, C.A. (1965). Methods of soil analysis. Part 1 and 2. American Society of Agronomy. Madison, Wisconsin.

Carvajal, L. H., S. Ordua and J. Bissett (2009).Growth stimulation in bean (Phaseolus vulgaris L.) by Trichoderma. Biological Control, 51: 409-416.

Collins, C.H. and P.M. Lyne (1980). Microbiological methods. Butterworths, London, 4: 215-217.

Cottenie, L., M. Verloo, L. Kiekens, G. Velghe and R. Camerlyck (1982). Chemical Analysis of Plants and Soils in Laboratory of Analytical and Geochemistry. Slate Univ., Ghent Belgium, 33-111.

Hegazi, A.Z. and A.M. Algharib (2014). Utilizing compost tea as a nutrient amendment in open filed cowpea seed production system. Journal of Biodiversity and Environmental Sciences, 5(2): 318-328.

Hicks, E., D. Bienkowski, M. Braithwaite, K. Mclean, R. Falloon and A. Tewart (2014). Trichoderma strains suppress Rhizoctonia diseases and promote growth of potato. Phytopathologia Mediterranea,53(3): 502-514.

Klute, A. (1986). Methods of Soil Analysis. Physical and Mineralogical Properties. American Society Agronomy Incorporator Madison, Wischogton, USA.

Lal, B. and B.P. Rana (2013). Evaluation of fungi as seed and soil treatment against root knot nematode, meloidogyne incognita in Okra. Agriculture Sciences Digastrics, 33 (3):226 - 229.

Lambers, H., F. S. Chapin and T. L. Pons (2008). Plant Physiological Ecology. 
Second Edition, (Springer Science, LLC, 233, New York, USA).

Masciandaro, G., B. Ceccanti, V. Ronch, S. Benedicto and L. Howard (2002). Humic substances to reduce salt effect on plant germination and growth. Commun Soil Science Plant Annals, 33:365-378.

Mastouri, F., T. Bjorkman and G.E. Harman (2010). Seed treatments with Trichodermaharzianum alleviate biotic, abiotic and physiological stresses in germinating seeds and seedlings. Phytopathology, 100: 1213-1221.

Moghaddan, M.J., G. Emtiazi and Z. Salahi (2012). Enhanced auxin production by Azospirillum pure cultures from plant root exudates. Journal Agriculture Science Technology, 14: 985-994.

Mosa, A.A. (2012). Effect of humic substances application on potato tubers yield quantity, quality, nutrients concentration under Egyptian soil conditions. DOI: 10.1007/978-94-0074104-1 27. In book: Sustainable potato production: Global Case Studies, Publisher: Springer, +Business

Nardi, S., P. Carletti, D. Pizzeghello and A. Muscolo (2009). Biological activities of humic substances. In: Senesi N, Xing B, Huang $\mathrm{PM}(\mathrm{eds})$ Bio physic-chemical processes involving natural nonliving organic matter in environmental systems. Vol 2, part 1. Fundamentals and impact of mineral, organic, biota interactions on the formation, transformation, turnover, and storage of natural nonliving organic matter (NOM). Wiley, Hoboken, pp. 305339.

Paul, J., A. K. Choudhary, S. Sharmac, S. Savita, M. Bohrae, A.K. Dixitf and P. Kumarg (2016). Potato production through bio-resources: Long-term effects on tuber productivity, quality, carbon sequestration and soil health in temperate Himalayas. Scientia Horticulture, 213 (14) :152-163.

Piper, C.S. (1950). Soil and plant analysis, Inter. Science, Publishers. INC, New York, USA. Culture.

Rasool, A., H. Behzad and G. Abolfazl (2011). Effect of Trichoderma isolates on tomato seedling growth response and nutrient uptake. African Journal Biotechnology, 10(31): 5850-5855.

Russo, R.O. and G.P. Berlin (1990). The use of organic bio-stimulants to help low input sustainable agriculture. Journal Sustainable Agriculture, 1:19-42.

Sania, B. (2014). Foliar Application of Humic Acid on Plant Height in Canola. APCBEE Procedia, 8: 82 -86.

SAS (2003). Statistical Analysis System SAS Users Guide : Statistics

Selim, E.M., A.A. Mosa and A.M. El-Ghamry (2009). Evaluation of humic substances fertigation through surface and subsurface drip irrigation systems on potato grown under Egyptian sandy soil conditions. Agric. Water Management, 96: 1218-1222.

Shanmugaiah, V., N. Balasubramanian, S. Gomathinayagam, P.T. Monoharan and A. Rajendran (2009). Effect of single application of Trichoderma viride and Pseudomonas fluorences on growth promotion in cotton plants. African Journal Agriculture Research, 4(11): 1220-1225.

Suganya, S. and R. Sivasamy (2006). Moisture retention and cation exchange capacity of sandy soil as influenced by soil additives. Journal Applied Science Research, 2: 949-951.

Suh, H.Y., K.S. Yoo and S.G. Suh (2014). Tuber growth and quality of potato (Solanum tuberosum L.) as affected by foliar or soil application of fulvic and humic acids. Horticulture Environmental and Bio-technology, 55(3):183-189.

Verma, J. P., J. Yadav, K. N. Tiwari and A. Kumar (2013). Effect of indigenous Mesorhizobium spp. and plant growth promoting rhizobacteria on yields and nutrients uptake of chickpea (Cicer arietinum L.) under sustainable agriculture. Ecological Engineering journal, 51: 282-286.

Zayed, M. S. (2012). Improvement of growth and nutritional quality of Moringa oleifera using different bio fertilizers. Annals of Agriculture Science, 57(1): 53-62. 
تأثير حامض الهيوميك ومحفزات النمو وطرق الاضافة علي صنفين من البطاطس المنزرعة تحت ظروف الاراضي الرملية

\author{
ممدوح محمد عرفة(1) ، محمد احمد الحويطي(2)

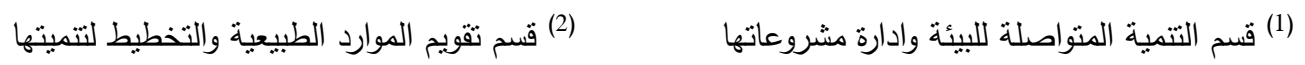

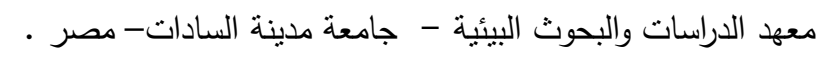

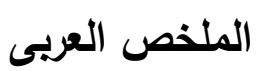

أجريت تجربنان حقلينان في مزرعة معهد الدراسات والبحوث البيئية - جامعة مدينة السادات خلال موسمي

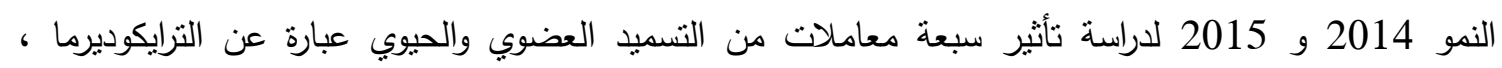

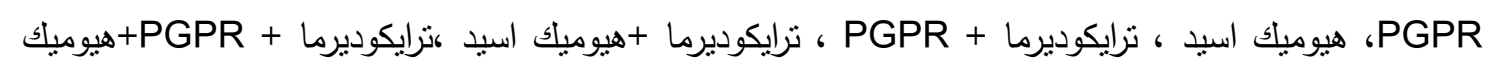

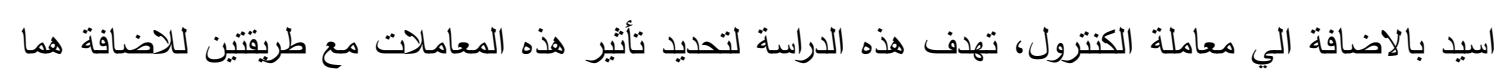

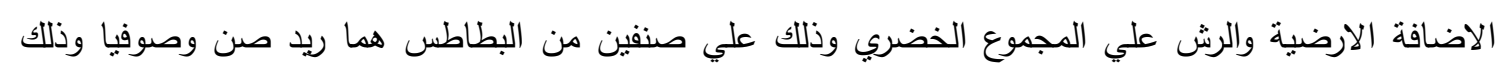

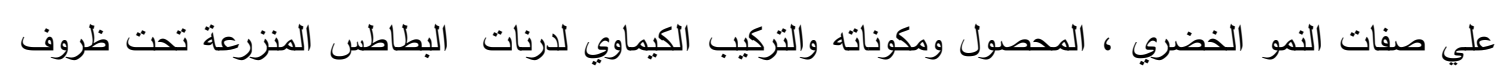
الاراضي الرملية .

أوضحت النتائج المتحصل عليها ان طول النبات ، عدد الافرع والوزن الطازج للنبات ، متوسط وزن الدرنة

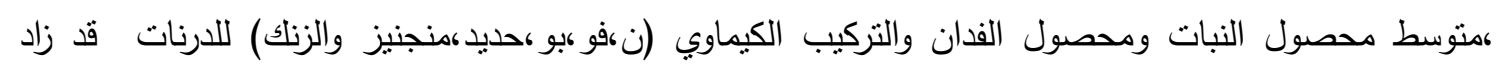

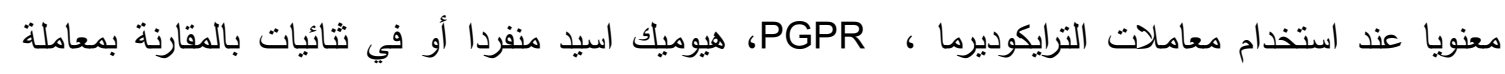

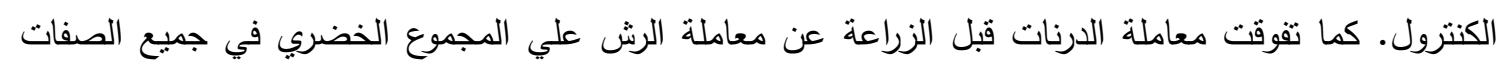

محل الدراسة

وتفوق صنف ريد صن علي صنف صوفيا في جميع الصفات محل الدراسة .

اما عن التأثير المشترك (التفاعل) بين الاصناف ومعاملات التسميد الحيوي فقد تفوق صنف ريد صن صن مع كلا من معاملة التريكوديرما وحمض الهيوميك و PGPR بالمقارنة بالكنترول، اما التاثير المشترك بين الاصناف لئن وطرق الاضافة فقد تفوق صنف ريد صن مع طريقة معاملة الدرنات قبل الزراعة .

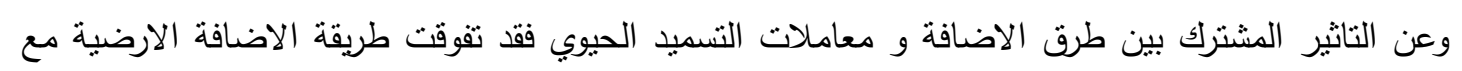

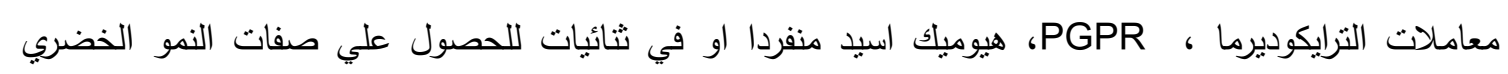

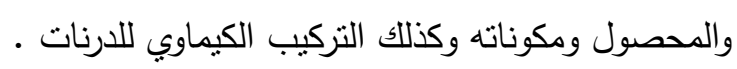
ويصفة عامة يمكن التوصية باستخدام (زراعة) صنف ريد صن مع معاملة الدرنات قبل الزراعة بالتسميد وكيد الحيوي للحصول علي افضل النتائج بالنسبة للنمو الخضري والمحصول ومكوناته والتركيب الكيماوي لدرنات البطاطس تحت ظروف الاراضي الرملية. 
Effect of humic acid, plant growth promoting and methods of .................. 